Article

\title{
Overt and Covert Buddhism: The Two Faces of University-Based Buddhism in Beijing
}

\author{
Joseph Chadwin \\ Department of Religious Studies, University of Vienna, 1300 Vienna, Austria; chadwinj64@univie.ac.at
}

Received: 23 January 2020; Accepted: 12 March 2020; Published: 16 March 2020

\begin{abstract}
As more and more students in China turn to religion, it follows that an increasing number of students in Chinese universities self-identify as Buddhist. Chinese academia has a tendency to treat this as problematic, offering reasons for this trend as well as solutions but neglecting to examine the nature of student belief and identity. By utilising two case studies, this paper seeks to demonstrate how the Buddhist identity and practice of self-proclaimed Buddhist students in Beijing can manifest in two very different ways: overtly or covertly. More specifically, each case study provides an example of students in Beijing who very much break with the commonly held perception that students in China who self-identify as religious have a fundamentally flawed and limited understanding of their religion and rarely actually practice it.
\end{abstract}

Keywords: Chinese students; Buddhism; religious identity; Beijing

\section{Introduction}

Student religiosity in China is a somewhat obscure field. On the surface level, one might think that it is a field that has, of late, received much academic attention. It is certainly true that there are multiple recent studies that focus upon the religious beliefs of university students in China. Indeed, 2008-2010 witnessed particular interest in the field with nearly 200 papers being published in the China Academic Journals (zhōngguó zhī wăng shùjùkù中国知网数据库) ${ }^{1}$ about the rise of religious belief among Chinese university students (Zhongguo zhi wang shuju 2019). However, the overwhelming majority of these studies (Zuo 2005; Gao 2005; Li 2006; Yang 2009; Chen 2010; Zhao 2011; Zhang and Wang 2012; Riyila 2015) address student religiosity as a problem to be solved. Zhang Shuwen and Wang Xue, for example, write that "university students' religious beliefs have become a problem that society cannot ignore" (Zhang and Wang 2012, p. 94). It is for this reason that I believe that much of the existing scholastic work pertaining to student religious belief in China is rather lacking: by focusing upon the reasons and causes for the "problem" as well as suggested "solutions", these works neglect to examine the very nature of student religious belief. Even though it is undeniably valuable examining why students increasingly turn to Buddhism (indeed, this paper shall also add to this dialogue), I hold that this is only part of the picture: how students practice Buddhism and how they conceive of their own Buddhist identity is a subject that is severely lacking in examination. This paper hopes to begin to address exactly this. More explicitly, I intend to shine light upon the nature of Buddhist identity among students in Beijing. By utilising two case studies from two separate universities in Beijing, I hope to show two very different ways that students in Beijing interact with Buddhism and form their own sense of religious identity. I specifically wish to present an alternative to the predominant themes in existing Chinese scholarship: namely that university students who engage in Buddhist

1 A Chinese article database that covers the vast majority of humanities and social sciences academic journals published in the PRC. 
practices have a fundamentally flawed and limited understanding of Buddhism and rarely actually practice their religion. By presenting two university case studies that show two extremely different manifestations of dedicated Buddhist practice, this paper intends to offer not only a valuable insight into student-run Buddhist societies, but also specifically demonstrate an alternative to this problematic predominant view.

According to the (albeit incomplete) official government statistics, since the beginning of the new century, the number of Chinese university students who possess "religious beliefs" (xìnyăng zōngjiào信 仰宗教) has increased and risen to nearly 15\% of the entire national student population (Riyila 2015). It has also been well documented that the religion that receives the most attention from students in China is Buddhism. This trend can be seen as early as the late 1980s when students were becoming an increasingly active, vocal, and confident group within Chinese society. Mak notes that during this time, with Chinese university students becoming more and more involved in several social and political activities which centred upon altruism, it was natural that Buddhism came into the lives of many students "despite the lingering aversion towards religious beliefs due to the Marxist-Leninist ideology" (Mak 2007). In 2009, the Ministry of Education (jiàoyù bù 教育部) carried out research pertaining to “the problem of young college students' faith” (qīngnián dàxuéshēng xìnyăng wèntíl青年大学生信仰问 题) in which three universities in Beijing were surveyed alongside one university outside of Beijing. According to their survey, a total of $21.9 \%$ reported that they regard themselves as religious with Buddhism contributing $12.5 \%$ to this (Huang 2014). Similarly, a survey of 832 students at Minzu University of China (zhōngyāng minzú dàxué中央民族大学) conducted by Wen Yingjie found that of the 83,278 students identified as Buddhist (Wen 2011). A very obvious part of and indeed (at least to a certain extent in Beijing) reason for this trend is the rise of student-run Buddhist societies. Established in the early 1990s, my first case study claims to be among the first of these societies.

\section{Research Aims}

The primary aim of this paper is to build upon the excellent work started by Ji and Han Qi. In 2006, Ji examined the phenomenon of rising youth religiosity in contemporary China (Ji 2006). Ji noted that in recent years, the Chinese Buddhist elite have done much to satisfy the needs of the Chinese youth: certain temples published periodicals, conferences were organised to which university students were invited, and summer camps were organised for young people. However, Ji also stated that "it is evident that the analysis of each case should be deepened, and some topics have not been highlighted" (Ji 2006, p. 546). Similarly, in 2014, Han Qi examined Buddhist university students in Beijing and argued that these students exhibited an extremely rational lifestyle (Han 2014). Although the main purpose of this article was to critique Weber's The Protestant Ethic and the Spirit of Capitalism, Han Qi concludes that we must develop new theories and descriptions of Buddhism that are suitable for the contemporary Chinese context. This paper intends to do exactly this. By presenting two extremely different case studies of university Buddhist societies in Beijing, this paper intends to theorise that university Buddhism in Beijing can manifest in two extremely different ways. More explicitly, I will propose two new categories of university-based Buddhism: overt Buddhism and covert Buddhism. The former category, as the name suggests, refers to students who practice Buddhism in an overt manner. By this, I specifically mean that these students openly identify as Buddhist to those around them and do not hide the fact that they engage in Buddhist practice. Covert Buddhists are quite the opposite of this. Students who fall into this category keep their Buddhist identity hidden from the public eye and very much practise in secret.

I will argue that the evidence from both case studies suggests that overt and covert Buddhists initially encounter Buddhism in extremely different ways: overt Buddhists find Buddhism through any of the five proposed means (namely university societies, classes and public lectures, off-campus Buddhist groups and sites, private and personal means, and family) whereas covert Buddhists encounter the religion predominantly through their own private means. In order to come to this conclusion, I will build upon Mak, who wrote a 2007 paper that, while only offering a very broad 
introduction, nevertheless grants insightful reasons as to why students in China choose to practice Buddhism. He proposed that students in China encounter Buddhism in one of four ways: classes and public lectures, university society activities, off-campus activities, and study groups (Mak 2007). I will develop each of these categories, tying them to both of my case studies, as well as add my own.

This paper shall also build upon and critique the work of Moser (2013), who, in turn, built upon the work of Jones (2010). Although neither focused upon university students specifically, instead providing far wider-reaching studies that examined the overall practice of Buddhism in Chinese cities, each have provided an invaluable insight into urban Buddhism that proved to be an ideal foundation for my own study. Of greatest relevance to this paper is Moser's identification of three distinct types of Buddhists in China: problem solvers, seekers, and lifestyle Buddhists (Moser 2013). Although Moser's study is undeniably valuable, by applying the findings from my two case studies to each of Moser's categories, I intend to highlight the flaws of each category.

Finally, this paper intends to move away from the prevalent trend in Chinese academia that holds that student religiosity is a problem to be solved. I intend to do this by critiquing the work of Riyila that perfectly encapsulates this problematic sentiment. After examining the religious beliefs of university students in China, Riyila came to three major conclusions based upon both pre-existing data as well as his own investigations (Riyila 2015):

1. The degree of understanding of religion among university students with religious beliefs is not very deep. Multiple university students who claim to possess religious identity do not understand or comprehend the very basic content of their own religious beliefs.

2. Many of the groups of students who practice religion together only participate in religious activity at a very low and unreliable frequency.

3. The degree of understanding of relevant religious policies are not very deep among university students.

Continuing on in the vein of Chi, who in 2014 interviewed educated Buddhist youths in China and noted a distinct intellectual vigour marked by a strategic analysis of their belief, science, and superstition (Chi 2014), I intend to apply each of these findings to my two case studies and by doing so, show that each conclusion is, at best, too sweeping and at worst, incredibly problematic.

\section{Methodology}

Conducting ethnographic research in China, especially research pertaining to a controversial area such as religion, is somewhat sensitive. Despite the fact that (non-Tibetan) Buddhism along with Confucianism are comparatively the least sensitive religions in contemporary China, scholars have, in the past, been hindered by the police while conducting research (Jones 2010). Thankfully, I did not experience any such obstacles. The largest obstacle I faced was knowing where to begin. I am utterly indebted to the friends I made while I myself was a student in Beijing. Without their help, it would have been nigh impossible for me to gain access to University B's Buddhist society. Solinger speaks of the importance of retaining all of one's old contacts in China "no matter how trivial" (Solinger 2006, p. 158). It was only through sheer luck that I learned of a Buddhist discussion group (tăolùn bān讨论 班) at University B: a former contact brought the group's existence to my attention. Learning of the existence of and then, subsequently receiving access to the society at University B, was, by far, the most difficult obstacle of this paper and I am acutely aware of the luck that factored into my eventual access. Thus, this paper differs from, for example, the work of Jones (2010) who may not have received access to similar societies due to not having an appropriate insider to point her in the right direction. Indeed, herein one finds the first noticeable manifestation of a notable difference between overt Buddhist students and covert Buddhist students: it was exceedingly easy for me to gain access to University A (the overt student Buddhist society). In total contrast, University B's Buddhist society (the covert student Buddhist society) was hidden to the extent that it was only through sheer luck that I was able to learn of their very existence in the first place. Moreover, gaining true access (namely access that 
allowed me to see that the society is in fact a dedicated Buddhist group rather than a study group) to the University B's Buddhist Society took four months. Therefore, one can already begin to note a key difference between overt Buddhist students and covert Buddhist students: the former are extremely easy to find and contact, whereas the latter are comparatively hidden and difficult to contact.

Regarding the research itself, I, like Arthur, adopted Harvey's concept of "guesthood" (Harvey 2005, pp. 227-28, 2013, p. 94) as an ethnographic research method: establishing relationships with my interviewees built upon mutual respect whereby meetings are "less like formal interviews with one-way exchange of information and more like mutually constituted relationships where knowledge is exchanged and discussed" (Arthur 2019, p. 16). By undertaking a far more intimate and less sweeping study compared to Riyila, who based his findings on official census data and statistics from relevant university departments that he himself acknowledges to be incomplete, I hope to offer an insight into university Buddhism that goes far beyond a surface level view. I therefore joined in with the activities of both societies and developed relationships whereby I felt as though my interviewees were very comfortable speaking to me. Once this relationship had been established, I found that my student interviewees were more than happy to discuss their involvement with their respective society as well as their own Buddhist identity and practice.

My sample size consists of 22 students from University A. These students made up the core membership of the university society. It should be acknowledged that, technically speaking, University A has far more than 22 members. Their WeChat (weixinin微信) group consists of hundreds of current students. However, I found that it was 22 students who very much made up the core of the society. It was these students who would consistently attend meetings and events. It should therefore be acknowledged from the outset, that even though I will, at times, refer to the wider, more sporadic membership base of University A, this paper predominantly relies upon the data obtained from the 22 core members. My sample size also consists of 19 students from University B who made up the entire membership of University B's Buddhist society. I conducted 22 formal semi-structured interviews with the core membership of University A's Buddhist Society as well as 19 formal semi-structured interviews with the entire membership of University B's Buddhist society. I closely followed each society from September 2018-September 2019, conducting participant observations on a weekly basis. All names, including the names of both universities, have been anonymised.

\section{Case Study 1: University A}

This section shall provide an overview of my first case study: the overt Buddhist student society found at University A.

Rather surprisingly, I was told that it was a very quiet year for the society as a whole. This was not the impression I received at all. I first met the society during the university societies fair. Dressed in matching society uniform, three representatives handed out leaflets to the backdrop of Buddhist music $^{2}$ and discussed Chan (chán禅) with passing students in the hopes of recruiting new members. These society members were exceptionally friendly and, above all else, wished to portray to prospective members how accessible their society is. Although the three of them self-identified as Buddhists, they wished to make it abundantly clear that the society is open to everyone. Responding to my question about who the society is for, one of them answered:

"This society is for everyone. From students who are just a little bit interested to lifelong

Buddhists, we welcome all."

They rather liberally kept coming back to joking about how what their society practices is not "mysterious and ineffable" (xuán ér yòu xuán玄而又玄) ${ }^{3}$. I was instantly struck by how open and

2 The students referred to the music as “佛乐” (fú yuè: Buddha music).

3 This is famously part of the opening of the Daodejing (dàodé jīng: 道德经). 
confident the society was about their practice of Buddhism. I later found out that the society was even featured in an article about this particular societies fair by Life Academy (yuánzhuō jiàoyù jījīn huil 圓 桌教育基金會). I believe that this is of great significance given that Life Academy, who are known for publishing articles pertaining to matters of education in Beijing, heavily draw from the work of Beijing Youth Daily UTF8gbsn(běijīng qingnián bào北京青年报) journalists who, it goes without saying, heavily push the party line. I believe that the significance here is that the article clearly shows just how normalised University A's Buddhist Society is. The reporter describes them in an exceptionally casual manner and seems to make nothing of the society being a religious group. Moreover, the reporter opens the article by writing that this particular societies fair consisted of 169 different society stalls. The article then goes on to describe 10 of these 169 societies, one of them being the University A's Buddhist Society. Rather than being swept under the rug, it is clear that the Buddhist Society of University A is simply seen as a very normal student society.

I found the weekly activities of the society to be very packed. They conducted a daily ${ }^{4}$ morning meditation session as well as an evening meditation session once a week. These took place in a rather beautiful meditation room situated in an idyllic location on the scenic part of campus. I was told that the society had received special permission from the university to make regular use of this room. These sessions were usually attended by approximately 15-20 students. However, during exam season, these sessions became especially popular (the highest number while I was in attendance was 65). The meditations were always guided. Sometimes it would be a society member leading it and other times it would be one of the Buddhist monks studying at the university. Fa Yin, who attended nearly every session that I was present for, described the sessions thus:

"I actually think that the Sutras are kind of straight forward about this. Meditation is the key to happiness. I actually joined this society because I was curious about the benefits of meditation and I hoped that it would help me with stress. At the time, I did not think that I would become a Buddhist myself. But when I felt that the meditation meetings were making such a big difference in my life, I decided that I wanted Buddhism to play an even bigger role in my life. Today, I cannot imagine my life without meditation. Whenever I feel stressed about my studies, I know that meditation will help me."

Similarly, the president of the society spoke of the importance of meditation to the society:

"Personally, I think that meditation is the very heart of our society. We all have problems in our lives and I think that meditation is a way of coping with these problems. The Buddha only needed to meditate for 49 days but we are not so lucky!"

When I asked him to elaborate, he explained:

"After 49 days, the Buddha reached enlightenment. I have been meditating for hundreds of days and I am still not there. We therefore all need to keep meditating as much as we can!"

From the core membership of the society, the overwhelming impression I gathered was one of impressive dedication to practice. I think one can safely argue that daily meditation practice is both regular and dedicated. I believe that herein, one find a contradiction to Riyila's assertion that religious students practice their religion at very low and unreliable frequencies. If I were to even compare the frequency of meditation meetings of this society to, for example, student-run Buddhist societies in the UK, the University A's Buddhist Society has a far higher frequency than the overwhelming majority of UK Buddhist societies who, I have found, have 1-2 meditation meetings a week.

I was especially surprised at the extent of religious conviction among the regular attendees. Of the 22 core members, 20 stated that they very much self-identify as Buddhist. However, during exam

4 This was every week day without fail and usually every weekend as well, unless a larger society event (such as a temple visit) was planned. 
season when the meditation session attendance skyrocketed, the vast majority of new students did not self-identify as Buddhists. In contrast, these students saw the meditation sessions as a temporary means to an end. Yu Chan, one such student, summed up the general view of these students. She told me in very clear terms:

"No I am not a Buddhist. My Aunt is a Buddhist but I am not."

She then, in response to my asking what brought her to this particular session, replied:

"I am very stressed these days. I have a lot of exams and I am very scared that I will fail. My parents keep telling me that I have to do well but I am so worried that I will let them down. One of my friends told me about this group and said that the meditation sessions are really good at helping with stress."

On top of these meditations sessions, the society also met at least once a week ${ }^{5}$ for "discussion groups" (tăolùn bān讨论班). The president of the society informed me that each semester, the society "systematically studies Chan doctrine" in both historic and contemporary China, as well as Buddhist philosophy in general. He said that the aim was for each society member to "fully understand Chan and Buddhist culture." These meetings, to say the very least, were an utter contrast to Riyila's conclusion that students with religious identity possess a limited understanding of their own beliefs. Every single student who attended these meetings appeared (and also confirmed in my interviews) to be exceptionally engaged with what I can only describe as a rigorous and academic study of Buddhist doctrine. Meetings would usually revolve around a particular text. The society would discuss the text in depth, often comparing it to other Buddhist texts. To my knowledge, each of the regular attendees ${ }^{6}$ had a strong knowledge of the Chinese Buddhist canon that far surpassed my expectations. Indeed, I often struggled to keep up with these sessions. The conversation flit quickly between in-depth analyses of, for example, the Blue Cliff Records (Biyan Lu碧䉷錄), to making Buddhist jokes, to discussing how the texts can be applied to their own lives. Ai Zuang, a third year mathematics student who was usually the one to organise and run these sessions, told me:

"I think that as Buddhists it is crucial that we are constantly doing our best to study Buddhism. Today there are many examples of false and half-baked Buddhist teachings so I think it is important to keep studying! For me, it makes a really big difference to be able to study and talk to my fellow students."

I was particularly interested in his identification of "false belief in Buddhism" (wěi xìn fó 伪信佛) and "half-baked Buddhist teachings" (bàn diào zì xìn fú 半调子信佛). These were concepts that came up regularly in the group's discussions. I felt that there was a very real desire within the group to stay true to what they perceived to be as the true teachings of Buddhism. Indeed, in a very potent contrast to Riyila, they had an extremely strong desire to go far beyond the mere basic content of Buddhist belief. This was very much a group of students who were deeply proud of their own Buddhist identity.

Although the meditation sessions and the discussion groups made up the main bulk of society activity over the year, the society also frequently (at least every other week) convened for social activities. Dinners were often arranged, karaoke remained something of a staple society evening social event, and from time to time, the group would meet to watch a film together. What struck me about these meetings was the extent to which these otherwise typical Chinese students were united by a shared Buddhist identity. At meals, conversation usually landed upon Buddhism. Movie nights usually revolved around kung fu ( $g \bar{o} n g f u$ 功夫) films, during which society members would often joke about how the film does not truly align with Buddhist doctrine. At karaoke, the students would often

5 These meetings were, more often than not, more frequent than once a week with the most being four times a week.

6 Exactly the same students who regularly attended the meditation sessions. 
(to much laughter) change song lyrics to incorporate Buddhism: my personal favourite was when, after the group had been discussing the nature of $a n \bar{a} t m a n^{7}$ (wú wó无我), the very popular chorus of "You exist in my song" (wǒ de gēshēng lǐ 我的歌声里) was changed from "you exist" (nǔ cúnzài你 存在) to “you cannot exist" (nǐ bù kěyi cúnzài你不可以存在). I found that the newsletters very much reflected this picture of typical Chinese students united by a shared Buddhist identity: newsletters flitted between outlining the overall themes of upcoming discussions such as "the world is not real" (shijiè shì bù zhēnshí de世界是不真实的) and "can one truly overcome ignorance?" (nǐ zhēn de nénggòu dăpò wú ming ma你真的能够打破无明吗) to distinct images of Chinese youth culture such as pineapples wearing sunglasses (which were particularly lost on me).

The University A's Buddhist Society also organised and ran several large-scale events throughout the year. During my time with them, they organised several lectures, discussions, and workshops headed by those from the academic community as well as those from the monastic community. Master Ming Xian of Behai Temple (北海寺), for example, conducted a Dharma talk followed by a meditation workshop. Moreover, visits to local temples and monasteries were organised as well as an incredibly popular summer retreat. To my surprise, these lectures and visits often attracted hundreds of students from across campus. I believe that it is particularly worthy of mention that the society shares a very close relationship with Longquan Monastery (lóngquán si龍泉寺) that is situated in Fenghuangling Nature Park (fènghuáng ľ̌ng凤凰岭) in the Heidan District (hăidiàn qü海淀区) about 18 miles away from downtown Beijing. The city of Beijing itself is totally devoid of functioning Buddhist temples and monasteries. Longquan Monastery is one of the two major officially recognised sites for Buddhist practice in the area. That the University A's Buddhist Society has such close ties with Longquan Monastery is of great significance. Mei You, a very devoted member of the society, volunteered at Longquan Monastery every week on Sundays. In an insightful discussion, she told me:

"Longquan is very special to me. I love that as a society we can discuss and practice Buddhism together, but none of us are experts. I think it makes a very big difference that we are also able to go to Longquan to learn from masters as well as be in a place that really makes us feel close to the Buddha."

I asked her to elaborate upon what she meant by closeness to the Buddha. Her answer was most revealing:

"Longquan is a truly sacred place. Every day, the monks do intense daily recitations and worship. You can really feel it when you visit. You can feel how good the karma is. They even have a special ceremony to purify karma twice a month. To all of us [in the society] this is of great benefit to our practice when we visit. I love Beijing, but the karma here is [she laughs at this moment]. Therefore, learning from and being in the presence of eminent monks is important, but also just being in the place itself is helpful too."

Herein, I believe the significance is twofold. I think that such a close relationship with the monastery has allowed the members of the University A's Buddhist Society to develop an even greater sense of Buddhist community. The students have a physical place where they can learn from ordained members of the Sangha. Secondly, it grants the society a great deal of legitimacy. In 2005, Longquan was officially restored as a site of religious activity. Today, it continues to share a very good relationship with the government. Thus, by affiliating themselves with an officially recognised religious site, the University A's Buddhist Society has essentially been able to legitimise the Buddhist practice and identity of their own society.

Of Riyila's three major conclusions, it was only the third that I found evidence of in the University A's Buddhist Society. For the most part, students had very little to say when I asked them about 
government policy pertaining to the practice of religion. The president of the society was the one who gave me the longest answer. He stated:

"I know that religion is allowed in our country and the government do not have a problem with us practicing it. I know that we have official permission from the university."

Most of the society members I asked thought that my asking about official policy was rather a strange thing to ask about. It could therefore be argued that, in line with Riyila's assertion, the members of the society did not have a deep understanding of relevant policies relating to the practice of religion. However, it could also be argued that the word "relevance" should be reassessed. The impression that I received was that the students truly did not believe that my question was of particular "relevance" (let alone interest) to them. Indeed, rather than official government policy, the only policy they thought was immediately relevant to them was their university's policy. It could also be the case that the students were not comfortable talking to me about state policy and therefore, kept their answers brief.

\section{Case Study 2: University B}

This section shall provide an overview of my second case study: the covert Buddhist student society found at University B.

In utter contrast to the University A's Buddhist Society, finding the University B's Buddhist Society was not easy. There was certainly no Buddhist society present at this university's society fair. Indeed, when I asked one of the organisers of the fair, I was told that no such society exists. However, I was directed to a group who frequently meet every week to discuss Buddhism by a former Beijing contact who happened to know of the existence of this private group. Upon request and with permission, I was added to a WeChat group focused upon organising these Buddhist discussion sessions at University B. I obtained permission from the group to join these meetings. Over the next four months (from September to December) I attended each session (usually twice a week). Excluding myself, 19 students were part of this WeChat group and the meetings were usually attended by all 19. The content of these meetings was very similar to the discussion sessions held by the University A's Buddhist Society: Buddhist texts were discussed in a great deal of depth. However, this is where the similarities ended. The tone of the University B meetings were very serious. No jokes were made and the feeling was of a group of students who simply wanted to do a rigorous study of Buddhist texts. Moreover, in total contrast to the University A's Buddhist Society, absolutely none of the 19 students in the University B group self-identified as Buddhist. Instead, each responded to my question regarding Buddhist identity along the lines of "I am interested in Buddhism but I am certainly not Buddhist myself." Furthermore, when asked about the nature of their group, the students would respond with "We wish to academically study Buddhism. We have no interest in the practice but we enjoy reading and discussing the texts." The WeChat group chat reflected this serious nature: meeting times and places were discussed and various articles pertaining to Buddhist texts were posted (and sometimes discussed). My initial conclusion, therefore, was that there was no fruitful comparison to be made between the two societies. One was very much a religious group and the other was a study group that centred upon a religious topic. Moreover, given that none of the students self-identified as Buddhist, I was unable to apply Riyila's conclusions as these were not religious students.

My relationship with the group dramatically changed after spending four months with them. In January, I was invited to join them for a previously unmentioned (despite being very much present during my previous four months) type of meeting. After a discussion group session, we went to a classroom on campus that the students knew was currently empty. I was then informed that we would be having a group meditation session. Each student sat behind a desk and for 50 min we sat in total silence. There was no guidance to the meditation nor a preliminary discussion. I thus learned that the surface level Buddhist study group was also something of an undefined meditation group. I was fascinated to find that once I started attending the meditation sessions on top of the discussion sessions, the group became much more open with what they discussed with me. Of particular note, 18 of the 
19 students changed their answer to my question "do you self-identify as a Buddhist?" I therefore found that 18 out of 19 of the students did indeed self-identify as Buddhist but were initially reluctant to tell me. I thus learned that the students had something of a semi-secret ${ }^{8}$ meditation session after each discussion meeting. Therefore, herein one finds another example that contrasts with Riyila's first two conclusions: the depth and rigour of these students' study of the Chinese Buddhist canon contradicts Riyila's assertion that students with religious beliefs do not possess a deep understanding of their own religion, and I believe that having a meditation meeting twice a week can be described as regular practice.

I soon learned that 16 of the 18 who self-identify as Buddhist keep their identity hidden from everyone except the other members of the group (the other 2 telling only their respective families). I found that the main reasons for this were a mixture between two factors: face (miànzi面子) and caution. The concept of face is crucial to Chinese society. Every citizen of China is expected to have a deeply ingrained understanding of the social nuances of face: the ability to "feel the hurt that comes from public humiliation, and the desire to protect oneself [and by extension one's family] from public humiliation" (Schoenhals 2015, p. 67). I should emphasise, from the outset, that none of the students who privately identified as Buddhist believed that being more open about their religious identity would be a major loss of face. However, this said, they were concerned that having an open Buddhist identity was not worth it when weighed with the potential of face loss. This feeling was best exemplified by one student who told me:

"I think that China is very different to the UK. I feel as though religion is not really a problem where you come from. Even the song that every English person knows is basically about religion [he at this point sings the tune to "God Save the Queen"]. In China it is very different. Nobody talks about religion. It was never mentioned in school or in my textbooks. My parents never mentioned it and my friends never talk about it. The closest thing you get is Journey to the West but I don't think that's real Buddhism. I sometimes think that I would really like to talk to my friends about Buddhism but I don't think it would be very comfortable. I think they would think that I am strange."

This feeling of general discomfort towards his religious identity was echoed by the other members who self-identified as Buddhist. I did not get the impression that they thought that their religious identity would be a large problem with their friends and family, but there was enough of a feeling of discomfort to warrant keeping it a secret.

If anything, the feeling of caution was the more pronounced reason. I chose the term caution because fear would be too strong. None of the students were afraid but there was a strong feeling among each member of wanting to be careful. When I directly asked about their reason for caution, one student informed me:

"It is kind of complicated. In China, we are not allowed to practice Buddhism in public places. Our university is a public place so I think we need to be careful."

The university is, therefore, not aware of the presence of this unofficial society. Herein, I believe one finds an understanding of relevant government policies pertaining to the practice of religion that Riyila believes religious students do not possess. The revised Regulation on Religious Affairs (zōngjiào shìwù tiáoli宗教事务条例) which took effect on 1 February 2018, states:

Citizens are entitled to the right of freedom of religious belief (Id. art. 2 II 1.) ... [but] sites not appropriately designated as religious ones [are prohibited] from conducting religious activities, accepting religious donations, carrying out religious training, and organizing citizens leaving the country to participate in religious training, meetings, and activities (Id. art. 41.) (Zhang 2017). 
Although none of the students mentioned any specific policy, each one was aware of where religious practices are and are not allowed.

In contrast to the University A's Buddhist Society, the students of University B did not organise any events outside of the usual discussion groups and meditation sessions. Unsurprisingly, due to the unofficial nature of the society, they had no affiliation with any official Buddhist sites nor a relationship with any masters. Interestingly, when I mentioned the University A's Buddhist Society, the students of University B were immediately interested and engaged. They spoke of the society at University A with awe and I had the strong impression that they saw the society as something of a Buddhist society ideal. One student told me:

"They are really very amazing! I read about them all the time online. I would love [University B] to have a Buddhist group like that but I know it is impossible."

In contrast to my initial conclusion about the University B's group, I now believe that a comparison between this group and the University A's Buddhist Society can easily be made. The University B's Buddhist Society was, like the society at University A, very much a religious group. However, even though I believe that the members of each group shared similar religious convictions, the way in which these convictions manifested were extremely different. Herein, one finds the dichotomy between overt Buddhist students and covert Buddhist students: the students of the University A's Buddhist Society held open and loud Buddhist identities while the students of University B held secret and quiet ones.

\section{How Do Students in Beijing Encounter Buddhism?}

This paper shall now turn to what I believe are the most significant conclusions that can be drawn from my fieldwork. It should be noted that I have omitted from the following conclusions the 2 students from University A and the 1 student from University B who did not self-identify as Buddhist.

The evidence acquired from both case studies show that overt Buddhist students and covert Buddhist students differ in their initial encounter with Buddhism. Therefore, the question of how students encounter Buddhism is crucial to understanding the fundamental differences between overt Buddhist students and covert Buddhist students. Therefore, in order to properly assess each fundamental difference between overt Buddhist students and covert Buddhist students, this section shall examine how students in Beijing encounter Buddhism.

In 2007, Mak proposed that students in China encounter Buddhism in one of four ways: classes and public lectures, university society activities, off-campus activities, and study groups (Mak 2007). These reasons served as an excellent foundation for my own conclusions. Aside from the occasional rare exception, essentially everyone in China has at least an elementary understanding of Buddhism. However, surprisingly few today have a knowledge of Buddhism that transcends this elementary nature. In this section, I shall outline the ways in which I believe university students initially encounter Buddhism in a manner that goes beyond this basic understanding most people in China possess. Building upon Mak and using my own fieldwork combined with recent Chinese academic findings (Jones 2010; Zhao 2011; Zhang and Wang 2012; Moser 2013; Riyila 2015) as my foundation, I propose that students encounter Buddhism in either one or a combination of the following ways:

\section{University Societies}

Although religious activities are not permitted on any campus in China (or any public spaces, for that matter), university societies are often the first point of contact between students and Buddhism. Larger and more established student societies such as the University A's Buddhist Society sometimes have relationships with Buddhist organisations outside the university. The society therefore acts as something of a springboard through which students can encounter and engage with formal Buddhist establishments and institutions. The University A's Buddhist Society is very much an example of this. They were very well advertised and had a strong online presence. Unsurprisingly, many students had their first true encounter with Buddhism via this society. Of the core 20 members, 8 initially 
encountered Buddhism through the society. In contrast, only 1 member ${ }^{9}$ of the University B's society encountered Buddhism through their society. Due to the fact that both of my case study societies were made up of students who possessed serious religious convictions, I would like to move away from the assumed idea that student Buddhist societies are not made up of students who earnestly practice religion but are instead made up of students who simply "have an interest in Buddhism and/or traditional Chinese culture" (Mak 2007). However, it should be acknowledged that this is very much the image that these societies often wish to portray (as opposed to societies who meet in order to actively practice religion). The University A's Buddhist Society, for example, despite manifesting as a society that seriously practices, studies, and engages with Buddhism, very much seeks to advertise this more laid-back image of being a society filled with students who simply have an interest in Buddhism and Chinese culture in general: when describing the general ethos of the society, the president stated "we hope to continue to adhere to the characteristics of the society, and to further highlight the cultural connotation and practical value of the Chan culture, and to organise activities to serve the campus and society." Similarly, although not advertised, the initial impression the students of University B wished to give me was of a non-religious group who were interested in academically finding out more about Buddhism.

2. Classes and Public Lectures

In contrast to pre-university education, which is totally secular and devoid of any religious content, major universities ${ }^{10}$ across China now offer classes on the history of Buddhism as well as Buddhist philosophy. With steadily rising applications from students seeking to learn more about Buddhism, formal university classes are a growing platform on which students in China are exposed to Buddhism. Furthermore, universities in China have been known to organise various public lectures by Buddhist leaders. However, of all of the five reasons, I believe that this is the least common. For the most part, students who enrol in these courses and attend these public lectures already have an established interest in Buddhism. Indeed, only 1 of the 20 students of the University A's Buddhist Society, who was also an official student of Buddhism at University A, and no students from University B (which, unlike University A, has no faculty of religion), initially encountered Buddhism through these means.

3. Off-Campus Buddhist Groups and Sites

Some students encounter Buddhism through official and non-official Buddhist groups and sites that exist off-campus. I found that student encounters with such groups and sites usually take place prior to attending university. As previously stated, although Beijing has no officially recognised temples open to the public (most having either been turned into tourist attractions or are reserved for internal activities for the Sangha) there are two major Buddhist centres that attract a great number of university students: Longquan Monastery and Bailin Monastery (bólin si柏林寺). Both of these sites organise several events that are specifically catered to university students. ${ }^{11}$ Although the former was of great significance to my first case study, it should be noted that none of the students from either case study initially encountered Buddhism from Beijing-based off-campus Buddhist groups and sites. Two students from the University A's Buddhist Society stated that their initial encounter with Buddhism was at the respective temples in their hometowns. No students from University B encountered Buddhism in this manner.

4. Private and Personal Means: Mass Media, Books, and Pamphlets

Many students encounter Buddhism through their own personal research. A plethora of websites, books, and pamphlets are dedicated to the teaching of Buddhism. Some students, instead of opting

9 This was due to the fact that this member happened to be best friends with one of the core members of the society.

10 An admittedly ambiguous term. The larger Chinese universities that receive a lot of international attention typically have departments that teach Buddhism. Peking University (Beijing), Renmin University (Beijing), Fudan University (Shanghai), Nanking University (Nanjing) and Zhongshan University (Guangzhou) are all obvious examples of universities that have experienced a steady growth of applications from students seeking to study Buddhism.

11 For an excellent insight into Buddhist summer camps, see: Wei Dedong's 2008 paper "Dangdai zhongguo zongjiao hong shi de fa zhan: yi shenghuo chan xialingying wei li." (Wei 2008). 
for a more social-based exposure, chose to peruse a more solitary route of personal research. A 2012 survey regarding student religious views found that $25 \%$ of students who regard themselves as religious found out about religion through the internet and $27.9 \%$ through books about religion (Zhang and Wang 2012). Three of the 20 students at University A's Buddhist Society encountered Buddhism this way. In contrast, 15 of the 18 students at University B encountered Buddhism via their own personal means.

5. Family

A common means through which university students in China encounter Buddhism is through their family. The aforementioned 2012 survey regarding student religious views found that $55.6 \%$ (by far the highest proportion of all responses) of students who regard themselves as religious do so because of their family (Zhang and Wang 2012). Needless to say, university students are deeply influenced by their family. It therefore stands to reason that many university students who identify as Buddhist do so because they come from a Buddhist family. It is often found that this is especially the case with minority ${ }^{12}$ university students. However, even though I accept that family is indeed a crucial means through which many students do indeed encounter Buddhism, neither of my case studies held this means as being the most common: 6 of the 20 students at University A and 2 of the 18 at University B. It should be acknowledged that the reason for this could have been due to the nature of my research samples. It is widely documented that the vast majority of students in China who possess a religious identity come from minority families. For example, officially speaking, the proportion of Tibetan students who believe in religion is $100 \%$, and the proportion of Hui (Huízú⿴囗十口族) students who believe in religion is 71.4\% (Zhang and Wang 2012; Huang 2014). Moreover, a recent study in Xi'an found that among the minority group students, $48.76 \%$ were religious in contrast to $10.34 \%$ of Han (hànzú 汉族) students (Wang 2016). Although I met a number of students from non-Han backgrounds at the University A's Buddhist Society, all 20 of my core sample were Han. Furthermore, none of the students from the University B's society were non-Han.

\section{Why Do Students in Beijing Choose to Practice Buddhism?}

The evidence from both case studies suggest that overt Buddhist students and covert Buddhist students choose to practice Buddhism for different reasons. However, in order to properly explore this finding, I believe that an initial, more general discussion of why students tend to choose to practice Buddhism is necessary.

Many Chinese academics hold that the predominant reason why students choose to practice Buddhism (and religion in general) is due to the current failings of the educational system (Zhao 2011; Zhang and Wang 2012; Huang 2014; Riyila 2015). Many hold that universities are not providing sufficient moral, social, ideological, and psychological education and guidance, and in response, some students turn to religion to fill this vacuum. I certainly do not seek to dispute whether or not this is indeed the case. Indeed, I find it of great significance that in a recent survey, when asked "are you presently satisfied with the ideological and political work of the higher learning institution?" only $28 \%$ of students surveyed responded with "satisfied" (Zhang and Wang 2012). However, I do believe that this is not the entire picture. Instead, I shall build upon the work of Moser, who identified three distinct, albeit non-mutually exclusive, types of Buddhists in China: problem solvers who came to Buddhism in response to a crisis or serious life trauma, seekers who are constantly looking for spiritual or religious meaning, and lifestyle Buddhists who view Buddhism as something more akin to a passionate hobby (Moser 2013). Although each of these categories hold much merit and are indeed valuable tools for assessing why people in China turn to Buddhism, I believe that they are not without their limitations. This section shall critique these categories by using the data obtained from both University A and University B.

12 Non-Han (hànzúi汉族). 


\section{Problem Solvers}

Seven of the 20 students from University A fell into this category and 15 from University B. Although I wholeheartedly agree with Moser that many students (although in his case, all people living in urban areas) choose to practice Buddhism in response to a problem they face, I do not agree with the extent that he outlines. I disagree with how he defines the term "problem": "problem solvers" convert to Buddhism in response to "a crisis or serious life trauma" (Moser 2013). However, I find that it is all manner of problems that cause students to turn to Buddhism, not only major ones. The "problems" in which students from both societies identified in their lives ranged greatly from general stress to the death of a loved one. One student from University B described what I believe to be a very typical student scenario in Beijing: he told me how university life was proving to be too stressful so he began practicing Buddhism in order to "seek spiritual support and psychological comfort" (xúnqiú jingshén jìtuō hé xīnlī annwèi 寻求精神寄托和心理安慰). Similarly, 5 students (1 from University A and 4 from University B) all referred to the same manner of stress by mentioning the same phrase: "unemployed as soon as one graduates" (yī bìyè jiù shīyè毕业就失业). Students are acutely aware that during their studies and upon graduation they will face immense competition. This inevitably leads to students feeling an enormous amount of pressure and stress that leads some to turn to Buddhism. One student from University B summarised this feeling by stating that "the current competitive nature of society is too fierce. The belief in Buddha is very steadfast and comfortable." Sometimes, the problem described to me was more existential in nature: students from both societies described having a "crisis of faith" (xinyăng wéiji信仰危机), others described more general feelings of confusion (găndào míwăng感到迷焵), and one student even claimed that he turned to Buddhist practice in order to "suppress dissatisfaction with reality" (yìzhì duì xiànshí de bùmăn qingxù抑制对现实的不满情绪). Furthermore, although they were not part of the core 20 members, it should be acknowledged that, to my knowledge, during exam season, when the University A's Buddhist Society's meditation sessions were attended by vastly more students than normal, these new students who only attended during exam seasons all attended in order to combat the stress that came with exams. Thus, while some students certainly fell into Moser's category - one student, for example, began practicing Buddhism in response to the death of her mother-I believe that reducing the term "problem" to major crisis is too limiting when, in reality, all manner of problems, both small and large, attract students to Buddhism. Indeed, two students (both from University A) described simply desiring “spiritual comfort" (jīngshén weiiji精神慰藉). Furthermore, Moser actively noted that "problem solvers" tended to be from low socio-economic backgrounds and with limited education. The very fact that I was working with students in Beijing who come from families who can afford to send their children to university means that I must disagree.

\section{Seekers}

Moser's "seeker" category are adults who have been on "a longstanding search for spiritual or religious meaning" (Moser 2013). Although it rather goes without saying that none of the students I interviewed fell into this category due to the simple fact of age, a number did very much come across as being at the beginning of such a journey. It could well be the case that in a few year time, these students might have turned into one of Moser's "seekers." Six students from University A fell into this category as well as two from University B. I noticed common phrases among these students such as "basic spiritual needs" (jīběn jīngshén xūyào基本精神需要) and the president of the University A's Buddhist Society told me that he thinks that what makes Buddhism so popular to students is that it “satisfies students desire for liberation" (mănzú tóngxuémen yāoqiú jiětuō de yuànwàng满足同学们要求解 脱的愿望). One student from University A explained that upon starting university he began to ask a plethora of questions about life. For him it was "Buddhism's unique interpretation and investigation of life and nature" (fójiào duì rénshēng, zìrán dútè de quánshì hé tànjiù佛教对人生、自然独特的诠释和探 究) that prompted him to practice. These students did not view their search for meaning as a problem. On the contrary, most of these students were most excited to describe their own personal search and the answers they eventually found in Buddhism. However, I believe that Moser somewhat limits this category by focusing too much upon those with "latent interest in metaphysical issues" (Moser 2013) 
while neglecting to mention a far more mundane seeker: namely those who seek self-improvement. While Moser identifies Buddhists who seek deep spiritual or religious meaning, or have an interest in metaphysical and philosophical questions, I believe that added to this are those who seek moral self-improvement. Indeed, five students from University A and one from University B described such a journey. These students came to Buddhism in order to improve their own moral character and become more focused (through meditation) in their studies and person. One student from University A actively stated that the main reason for practicing Buddhism and the main function Buddhism plays in life is to “improve one's moral character" (tígāo zìshèn dàodé sùyăng提高自身道德素养). Similarly, one student from University B explained to me how Buddhism granted her "social rules" (shèhuì guīzé 社会规则) that made all of the difference to her day-to-day life. Furthermore, another student from University A actively attacked the current moral state of the nation, claiming that she turned to Buddhist practice in order to gain something of a moral compass: "We are in a current state of spiritual desertification. Our generation has not paid much attention to ideology and morality. In the process of our schooling, only primary schools have ideological and political classes, and secondary schools have never grasped them, so there is no spiritual pillar." I therefore believe that Moser's seeker category could be improved by allowing for moral as opposed to religious/metaphysical seekers.

3. Lifestyle Buddhists

Moser's lifestyle Buddhists approach Buddhism like a passionate hobby whereby the "religion becomes part of their self-image, and they often exhibit their belief in evident displays such as distinctive dress, ornaments, [and] home shrines" (Moser 2013). I found that this category very much applied to University A. Absolutely every core member fell (although not exclusively) into this category. In contrast, this category could not be applied at all to University B. This finding shall be explored in the following section. Although this category is an extremely valuable way to view Buddhists, I also believe that it can be improved. I hold that Moser limits himself by stating that lifestyle Buddhists are attracted to Buddhism because it has become "cool": "Buddhism's trendiness in part comes from the host of media figures who embrace the religion" (Moser 2013). While I certainly do not dispute that this is often the case, I have found that some Buddhists become lifestyle Buddhists in order to reconnect with their family and culture. Although these Buddhists still treat the religion as part of their own self- image, it is not because they perceive Buddhism to be necessarily trendy. Two students from University A described their practice of Buddhism as a means of getting in touch with their own heritage. Identity formation played a large role in their reasoning with each student coming to Buddhism as part of a wider move to come to terms with and define their own identity. However, neither spoke of this identity as being the "cool" and "trendy" identity that Moser holds that lifestyle Buddhists have. One student told me that Buddhism used to play a major role in her family but this was no longer the case. She, therefore, began practicing Buddhism because she wished to reconnect with what she believed to be an important aspect of her family, that she was worried was in danger of dying out with her grandmother. The other student was currently in the process of coming to terms with and defining his own national identity. He explained that he started practicing Buddhism because "Buddhism is an important carrier of traditional culture" (fójiào zuòwéi chuántǒng wénhuà de zhòngyào zàitǐ佛教作为传统文化的重要载体). I therefore believe that there are essentially two manifestations of lifestyle Buddhists: the first is exactly as Moser describes-those who hold a "trendy fascination" (Moser 2013) with Buddhism and the second are those who seek to adopt a Buddhist identity that allows them to reconnect with their family and culture.

\section{How Do the Religious Identities, Beliefs, and Practices of Buddhist Students Manifest?}

Despite having an extremely small sample of two student Buddhist societies in Beijing, I believe that given how different each is, one can come to something of a tentative conclusion that the religious identities, beliefs, and practices of Buddhist students in Beijing can manifest in two exceedingly different ways:

1. Overt Identity, Belief, and Practice 
As the name suggests, these Buddhist students are very open, and indeed, often proud, about their own Buddhist identity. Everything about the students of the University A's Buddhist Society pointed towards this overt attitude. Buddhism played a very outward and obvious role in all of their lives. Their Buddhist identity was typically known to everyone who knew them and they would make very open displays of this identity: many wore Buddhist prayer beads (fózh $\bar{u}$ 佛珠), many used Buddhist images as their WeChat profile pictures, and a few even sometimes wore Buddhist items of clothing (such as t-shirts purchased from Longquan Monastery). To this end, absolutely every student from the core membership of this society was a lifestyle Buddhist: Buddhism played an extremely prominent role in their image and also interactions with others. They typically deeply enjoy discussing their Buddhist belief with their fellow classmates. It is this type of Buddhist student that academia, the media, and the public notices: when one finds mention of Buddhist students, it is of students who openly refer to themselves as being Buddhist. This is hardly surprising as Buddhists who fall into this category seem to do everything in their power to be seen. The Buddhist society of University A was officially recognised by the university and the society had a very active and visible online presence. Moreover, members actively tried to advertise the society and recruit new members. These Buddhists can fall under any of the five ways of initially encountering Buddhism and also any of, or indeed a mixture of, Moser's three categories. The overt Buddhist society of University A was, therefore, something of an all-encompassing student Buddhist society. These students were, for the most part, extroverted and more than happy to talk to me at length about their identity, beliefs, and practices.

2. Covert Identity, Belief, and Practice

These Buddhist students are a complete contrast to those with an overt identity, belief, and practice. Indeed, I believe that this group is rather similar to Moser's "invisible path" of Buddhists whose "religious participation is kept apart from their professional lives" (Moser 2013). It was the students of University B that exhibited these traits. These Buddhist students keep their Buddhist identity, belief, and practice hidden from absolutely all except their fellow secret practitioners. I was extremely lucky to even discover that University B had a group that met to discuss Buddhist texts, let alone eventually discover that this group was actually a religious group in disguise. Whereas the overt Buddhist students I interviewed initially encountered Buddhism for any of my five identified reasons and fell within any of Moser's categories, I found that covert Buddhist students predominantly initially encountered Buddhism through their own personal means and fell into the problem solver category. Therefore, students initially came to this society for one reason: to help solve a particular problem (or problems). Even though their own personal Buddhist identity meant a great deal to each of the Buddhist members of University B, none of them made any outward expressions of this identity. In further contrast to overt Buddhist students, covert Buddhist students, for the most part, were extremely shy and were initially reluctant to even talk to me about the texts that they were studying, let alone their personal Buddhist beliefs and practices that they initially kept hidden from me.

\section{Why Do Overt Buddhist Students and Covert Buddhist Students Practice in Seemingly Opposite Ways?}

Overt Buddhist students are defined by freedom. In their very being, overt Buddhists embody this term. They have the freedom to practice their religion in their university. They have the freedom to seek guidance from local experts. They have the freedom to openly express their beliefs in public. They have the freedom to actively seek out new members. The exact opposite can be said for covert Buddhist students. Without official recognition from their university, the students of University B lacked the freedom to operate in the same manner as the students of University A. Whereas overt Buddhist students are not troubled by the idea of losing face as a result of their Buddhist identity and have no need to be cautious about their religious activities and identity, covert Buddhists are troubled by the potential loss of face that their Buddhist identity could bring about and, more importantly, extremely cautious about their religious activities and identity. The importance of official backing cannot be diminished. With official backing, the students of University A were very much able to 
practice something that was seen to be as public religion. Without official backing, the students of University B were forced to engage in private practice of religion. With official university backing, the activities of overt Buddhist students become completely normalised and there is, subsequently, no risk of losing face. In contrast, without official university backing, covert Buddhists feel as though they are practicing something that is not normal. There is, therefore, danger of losing face (or even getting into trouble) should they opt to practice publicly. Therefore, one could argue that the answer to why overt Buddhist students and covert Buddhist students practice in seemingly opposite ways is simple: overt Buddhist students possess the freedom to act and identify as Buddhist whereas covert Buddhist students do not. However, one could also argue that this is an oversimplification of a far more complicated matter. Although it was very clear that the students of University B did not feel as though they possessed the freedom to openly act, this is not necessarily because they did not actively possess this freedom. Indeed, the founder of the group told me that they had never actually attempted to request permission from the university on the grounds that they were too worried about the possibility of the university denying their request. This uncertainty visibly worried the members of the University B's Buddhist Society and I very much got the impression that rather than attempt to receive permission and risk failure, the students were more comfortable keeping their society private. Moreover, I thought that it was extremely revealing that the majority of the members of University B's society told me that if they were to be open about their Buddhist identity, their respective families and friends would probably have no problem whatsoever. One could therefore argue that rather than the possession of freedom, the true underlying reason as to why overt Buddhist students and covert Buddhist students practice in seemingly opposite ways is due to opposing levels of confidence. The president of University A inherited charge of a long-established society with a long history of extremely active members. He inherited a culture of confidence and this set the tone for the entire society. In contrast, the founder of University B's Buddhist Society is a very soft-spoken, shy student that told me on three separate occasions that he struggles with social anxiety. In contrast to inheriting a large well-established Buddhist society, he quietly started his own and expressed a desire to "keep it small." Although it is too sweeping to claim that the differences between overt and covert Buddhist students are entirely down to how student Buddhist societies are run, I believe that it is very much the case that the founder of University B's society set the tone for how the society would be run. The students of University B all came across as shy and reserved and it could well be the case that they together cultivated a culture whereby this reserved attitude towards their religious identity has flourished. Indeed, one could therefore argue that the very fact that the society could, in theory, request permission from University B to function as a recognised society together with the fact that the majority claim that their friends and family would have no problem with their Buddhist identity, suggests that the private nature of covert Buddhist students is self-imposed rather than imposed. However, although one could certainly argue that they are secretive about their practice of Buddhism out of their own choice, the fact that the students actively express desire to be like the University A's Buddhist Society suggests that this is not necessarily the case. Therefore, one could argue that the core difference between overt Buddhist students and covert Buddhist students is that the former group are built upon a culture of openness and confidence whereas the latter is a group built upon a lack of confidence grounded in uncertainty. Needless to say, these conclusions are very much conjecture. However, the confidence I observed at University A was utterly contrasted by the lack of confidence I observed at University B.

\section{Conclusions}

Needless to say, the sample that this paper has drawn upon is extremely small: only two student Buddhist societies in Beijing have been examined. I, therefore, do not wish to offer any sweeping nor even anything other than tentative conclusions. Given this small sample size, I do not, for example, wish to claim that Riyila's claims have been disproved without a doubt. However, the very fact that this paper has outlined two extremely different student Buddhist societies that share an equal passion for 
Buddhism, a deep understanding of Buddhist doctrine, and practice on a very regular basis, is certainly evidence to contrast the predominant theme in existing Chinese scholarship: namely that university students who engage in Buddhist practices have a fundamentally flawed and limited understanding of Buddhism and do not frequently practice. Indeed, what binds these two groups together is exactly this shared love for Buddhism mixed with frequent practice and rigorous study. Furthermore, I believe that the very existence of University B's Buddhist Society is significant. In 2010, Jones concluded that she "was not able to discover any Buddhist student groups at any of Nanjing's many universities that meet in person, there are several university student discussion boards where people discuss Buddhism" (Jones 2010, p. 98). This is an unsurprising conclusion as the University A's Buddhist Society is something of a rare case: the norm in universities in China is to find absolutely no mention of an official student Buddhist society. However, the very presence of University B's Buddhist Society might suggest that there are more of its ilk. At the very least, I would be wholly unsurprised to find that universities across China possess far more covert Buddhist students than official statistics might lead us to believe. Finally, although I was initially hesitant to forward any form of a value judgement, the evidence I have gathered overwhelmingly suggests that overt Buddhism is the preferential of the two. The overt Buddhist students of University A were extremely happy in their identity. In contrast, even though they all spoke very highly of their society, the covert students of University B had a sense of longing: they wanted to be overt Buddhists but did not feel as though this option was possible. Indeed, whereas overt Buddhists students always had the option to be covert Buddhists by simply enacting their own private practice of Buddhism, covert Buddhist students, whether it is due to a lack of freedom or a lack of confidence, do not feel as though they have the choice to become overt. The fact that covert Buddhists are cautious and reserved is not necessarily a bad thing. However, the fact that the students of University B spoke of the University A's Buddhist Society with such a sense of awe and longing implies that they do not want to be cautious and reserved. Moreover, with the official recognition granted to overt Buddhist students comes the benefit of professional guidance from Buddhist experts, the freedom to practice openly, and support in advertising the society to new students. Of these benefits, I believe that the opportunity to receive professional religious guidance is of greatest significance. The students of University B were entirely on their own. Any questions that arose pertaining to their Buddhist practice could only be discussed amongst themselves. Many of them often spoke of the desire to receive professional guidance but none of them felt as though they could. In contrast, the students of University A were very quick to speak of the benefits of receiving guidance from the monks of Longquan Monastery as well as academics who focus on Buddhism.

Funding: Open Access Funding by the University of Vienna.

Conflicts of Interest: The author declares no conflict of interest.

\section{References}

Arthur, Shawn. 2019. Contemporary Religions in China. Abingdon: Routledge.

Chen, Guiping. 2010. Cong daxuesheng zongjiao xinyang kan gaoxiao zongjiao gongzuo. Shanghai shi shehui Zhuyi Xueyuan Xuebao 5. Available online: http://dysw.cnki.net/kcms/detail/detail.aspx?filename=KJSJ201410115\& dbcode=DJSJ\&dbname=DJSJ1418\&v= (accessed on 2 November 2019).

Chi, Shuai. 2014. Zhishi qingnian fojiao xinyang di queli: duì beijing diqu bufen xinzhong de fangtan. Zongjiao Shehui Xue 2. Available online: https://mall.cnki.net/magazine/Article/SWZS201400009.htm (accessed on 1 November 2019).

Gao, Shining. 2005. Dangdai beijing de jidujiao yu jidu tu. Hong Kong: Dao feng shushe.

Han, Qi. 2014. Rushi qian xiu: Dui beijing diqu san suo gaoxiao daxuesheng fojiao tu shenghuo yangshi de yanjiu. Zongjiao Shehui Xue 2. Available online: https://mall.cnki.net/magazine/Article/SWZS201400008.htm (accessed on 4 November 2019).

Harvey, Graham. 2005. Animism: Respecting the Living World. London: Hurst.

Harvey, Graham. 2013. Food, Sex, and Strangers: Understanding Religion as Everyday Life. Abingdon: Routledge. 
Huang, Yanhong. 2014. Beijing daxuesheng zongjiao xinyang diaocha yanjiu zongshu. Hongse wenhua wang. Available online: http://www.hswh.org.cn/wzzx/llyd/wh/2014-12-31/29513.html (accessed on 3 November 2019).

Ji, Zhe. 2006. Non-institutional Religious Re-composition among the Chinese Youth. Social Compass 53: 535-49. [CrossRef]

Jones, Alison Denton. 2010. A Modern Religion? The State, the People, and the Remaking of Buddhism in Urban China Today. Ph.D. dissertation, Sociology, Harvard University, Cambridge, MA, USA.

Li, Zhiying. 2006. Daxuesheng dangyuan xinjiao wenti diaocha (1) daxuesheng dangyuan xinjiao de renqun tezheng ji chengyin fenxi”, "daxuesheng dangyuan xinjiao wenti diaocha (2) daxuesheng dangyuan xinjiao de tedian. Kexue Yu Wushenlun 3. Available online: http://www.kxwsl.com/plus/view.php?aid=1251 (accessed on 1 November 2019).

Mak, Bill. 2007. Synergy or Collision: University students encountering Buddhism in China. Bodhi Journal 3. Available online: https://www.buddhistdoor.net/features/synergy-or-collision-university-studentsencountering-buddhism-in-china (accessed on 30 October 2019).

Moser, David. 2013. An Invisible Path: “Urban Buddhists" in Beijing and their Search for Meaning. In Restless China. Edited by Perry Link, Richard P. Madsen and Paul G. Pickowicz. Lanham: Rowman \& Littlefield Publishers, pp. 165-88.

Riyila, Yusufu. 2015. Dangdai daxuesheng zongjiao xinyang wenti sikao. Gongwuyuan qikan wang. Available online: https://www.21ks.net/lunwen/zjxylw/78457.html (accessed on 30 October 2019).

Schoenhals, Martin. 2015. The Paradox of Power in a People's Republic of China Middle School. Abingdon: Routledge. Solinger, Dorothy. 2006. Interviewing Chinese People: From High-level Officials to the Unemployed. In Doing Fieldwork in China. Edited by Maria Heimer and Stig Thøgersen. Copenhagen: NIAS, pp. 153-67.

Wang, Chao. 2016. Research Note: College Students' Attitudes toward Christianity in Xi'an, China. Religions 7: 58. [CrossRef]

Wei, Dedong. 2008. Dangdai zhongguo zongjiao hong shi de fa zhan: yi shenghuo chan xialingying wei li. Zongjiao Shehui Kexue Yanjiu 1. Available online: https:/fo.ifeng.com/special/sjz/shegnhuo/detail_2011_05/12/ 6345295_0.shtml (accessed on 20 February 2020).

Wen, Yingjie. 2011. Minzu gaoxiao daxuesheng zongjiao xinyang xianzhuang ji jiaoyu duice yanjiu: yi zhongyang minzu daxue wei li. Minzu jiaoyu yanjiu 3. Available online: http://edu.wanfangdata.com.cn/Periodical/ Detail/mzjyyj201103011 (accessed on 2 November 2019).

Yang, Huilin. 2009. Dangdai zhongguo daxuesheng dui jidujiao xinyang de lijie tezheng. Available online: http: //www.regentcsp.org/list_bbs.asp?id=287 (accessed on 2 November 2019).

Zhang, Laney. 2017. China: Revised Regulations of Religious Affairs. Library of Congress. Available online: https://www.loc.gov/law/foreign-news/article/china-revised-regulations-on-religious-affairs/ (accessed on 2 November 2019).

Zhang, Shuwen, and Xue Wang. 2012. Dangdai daxuesheng zongjiao xinyang zhuangkuang: Yi jing neiwai san suo daxue wei li. Heilongjiang Researches on Higher Education 9: 94-97.

Zhao, Liang. 2011. Dangdai daxuesheng zongjiao xinyang wenti diaocha fenxi yu duice yanjiu. Master's thesis, Jilin Agricultural University, Changchun, China.

Zhongguo zhi wang shuju. 2019. Available online: https://www.cnki.net/ (accessed on 2 November 2019).

Zuo, Peng. 2005. Beijing jidujiao xianzhuang diaocha. Beijing shi zhexue shehui kexue "shiwu" guihua xiangmu yan jiu baogao. Available online: http://kyc.uibe.edu.cn/glwj/bjswj/29235.htm (accessed on 1 November 2019).

(C) 2020 by the author. Licensee MDPI, Basel, Switzerland. This article is an open access article distributed under the terms and conditions of the Creative Commons Attribution (CC BY) license (http://creativecommons.org/licenses/by/4.0/). 